\title{
Epidemiological Pattern of Breast Diseases among Females in the South-Western Region, Saudi Arabia
}

\author{
Abdulrahman Manaa Alamri ${ }^{1}$, Saeed Ali Alsareii ${ }^{1}$, Hajr Hassan Al-Wadei ${ }^{1}$, \\ Awad Mohammed Al-Qahtani' ${ }^{2}$, Salem Ali Alatef Sultan³ ${ }^{3}$, Sara Ali Alshamrani', \\ Ahmed Hamzah Almakrami ${ }^{3}$, Abdullah Ahmed Daiel ${ }^{3}$, Ahlam Yahya Alyami, \\ Ashwaq Mousa Hommadi ${ }^{3}$, Yagoub Mohammed Tahir Ali ${ }^{4}$ \\ ${ }^{1}$ Department of Surgery, College of Medicine, Najran University, Najran, KSA \\ ${ }^{2}$ Department of Community Medicine, Faculty of Medicine, Najran University, Najran, KSA \\ ${ }^{3}$ College of Medicine, Najran University, Najran, KSA \\ ${ }^{4}$ Department of General surgery, King Khalid Hospital, Najran, KSA \\ Email: ^manaa_880@hotmail.com, alsareii997@hotmail.com,dr-hajr@outlook.sa,dr.awad2009@gmail.com, \\ drss_01@hotmail.com, sa36.ali@gmail.com,Ahmad6614@gmail.com, Abdullahdaiel@gmail.com, iahlam.yh@gmail.com, \\ Dr.ashwaqhommadi@hotmail.com, abutaher66@hotmail.com
}

How to cite this paper: Alamri, A.M., Alsareii, S.A., Al-Wadei, H.H., Al-Qahtani, A.M., Sultan, S.A.A., Alshamrani, S.A., Almakrami, A.H., Daiel, A.A., Alyami, A.Y., Hommadi, A.M. and Ali, Y.M.T. (2020) Epidemiological Pattern of Breast Diseases among Females in the South-Western Region, Saudi Arabia. International Journal of Clinical Medicine, 11, 257-269.

https://doi.org/10.4236/ijcm.2020.115027

Received: April 15, 2020

Accepted: May 12, 2020

Published: May 15, 2020

Copyright $\odot 2020$ by author(s) and Scientific Research Publishing Inc. This work is licensed under the Creative Commons Attribution International License (CC BY 4.0).

http://creativecommons.org/licenses/by/4.0/

\begin{abstract}
Background: Breast diseases cover several conditions. The majority of breast diseases are noncancerous. Some of these lesions are clinically unremarkable, which needed minimal intervention. However, some symptoms may be of clinical value and attract the attention of both the patient and the attending physician, especially when they become persistent. The study aimed to assess the prevalence, pattern, types, and clinical profile of breast diseases among females in the South-western region, during the period from 2018-2020. Methods: A retrospective record-based descriptive approach was used through reviewing medical records of all cases with breast disease attended King Khalid Hospital during the period from January 2018 to January 2020. Data extracted throng pre-structured questionnaire. Results: The study included 211 cases whose ages ranged from 18 to 58 years old with a mean age of $28.9 \pm 12.8$ years. Breast mass was the most recorded complaint (95.1\%) followed with breast pain (32\%), skin changes. Benign findings based on the final pathology report were recorded for more than two thirds of the cases, with the most common finding were fibroadenoma. Excisional biopsy and modified radical mastectomy were the most reported surgical interventions. Conclusions: In conclusion, the study revealed that the majority of the cases had benign breast disease (BBD), where fibroadenoma was the most frequent.
\end{abstract}




\section{Keywords}

Breast Disease, Females, Incidence, Pattern, Predictors, Epidemiologylesions, Biopsy

\section{Background}

Breast diseases make up several conditions. The majority of breast diseases are noncancerous [1] [2]. Breast lesions are mainly recorded among females. The most recorded cause of breast problems in females is a benign breast disease, which is 10 times more common than breast cancer in most countries [3]. Some of these lesions are clinically unremarkable, which needed minimal intervention. However, some symptoms may be of clinical value and attract the attention of both the patient and the attending physician, especially when they become persistent. The main item behind that concern is the possibility of the occurrence of breast cancer, which is usually asymptomatic in the early stages during which it is curable [4]. Benign breast diseases are mainly prevalent during the reproductive age as the incidence is common mainly in the second decade with realization on its peak at fourth and fifth life year's decade [5]. Benign breast diseases include many and variable histological patterns categorized into non-proliferative breast lesions, proliferative breast lesions without atypia, and proliferative breast lesions with atypia [6] besides fibroadenoma, fibrocystic change, and breast abscess are the most recorded benign lesions in the literature [7]. Certain types of benign breast lesions were recorded as a significant risk factor for developing breast cancer [8]. Women with benign proliferative or atypical breast lesions consume a two-fold risk of developing breast cancer in western populations [9].

The literatures covered the histopathological pattern of breast diseases with less attention for the clinical perspectives [10] [11] [12]. Surgical evaluation of the symptomatic patients by triple assessment, namely, clinical examination of the breast, mammography, and breast biopsy for definitive histological diagnosis is required in many patients [13].

The current study aimed to assess the prevalence, pattern, types, and clinical profile of breast diseases among females in the South-western region, during the period from 2018-2020.

\section{Methodology}

Retrospective record-based descriptive approach was used through reviewing medical records of all cases that were admitted and have breast disease (benign or malignant breast masses) in King Khalid Hospital during the period from January 2018 to January 2020. Records with missing data were included. Data extracted through pre-structured questionnaire including patient's bio-clinical data, initial clinical presentation of the breast disease, radiological assessment findings. Also, the final pathological findings were extracted besides the nature 
of the assigned pathology. Data also included the type of surgery and post operative outcome.

\section{Statistical Analysis}

After data were extracted, it was revised, coded, and fed to statistical software IBM SPSS version 22 (SPSS, Inc. Chicago, IL). All statistical analysis was done using the two-tailed test. A P-value of less than 0.05 is considered being statistically significant. Descriptive analysis based on frequency and percent distribution was done for all variables, including demographic data, breast disease nature, and types, clinical presentation, and surgery outcome.

\section{Results}

The study included 211 cases whose ages ranged from 18 to 58 years old with a mean age of $28.9 \pm 12.8$ years. Exact of $59(72 \%)$ of the females were married, and all of the sampled females started menstruation at the age of 18 years with regular menstrual cycle. Ten (67\%) of the females are still menstruating. Only one $(10 \%)$ of the study females had the first pregnancy before the age of 20 years and $10 \%$ above the age of 30 years. As for gravidity, 3 (10.3\%) of the females had no pregnancy, while $31 \%$ had four pregnancies or more. Considering co-morbidity, diabetes mellitus was recorded among 5 (9.6\%) of the females and 8 females (15.4\%) had hypothyroidism (Table 1).

Table 2 demonstrates the determinants of having breast disease. Oral contraceptive pills were received by 8 (40\%) of the study females, and $30.8 \%$ of them had hormonal therapy. A family history of breast disease, including breast cancer, was recorded for 4 females (23.5\%). Only 8 (44.4\%) of the females know about breast screening for early detection of breast lesions, while 23 females (85.2\%) do breast examination regularly. Only one case recorded that she performs regular breast screening after the age of 40 years.

Concerning clinical data of recorded breast diseases (Table 3), breast mass was the most recorded complaint as recorded for 196 females (95.1\%) followed with breast pain which was among 66 females (32\%), skin changes (11; 5.3\%), and nipple discharge $(8 ; 3.9 \%)$. The symptoms $=$ appeared for less than one month among $23.5 \%$ of the cases while lasted for more than 6 months among 52 females (39.4\%). As for the affected side, the right side was dominant among 84 females (41.2\%) of the cases while it was bilateral among 19 (9.3\%). The breast mass measured less than $2 \mathrm{~cm}$ among $60(37.5 \%)$ of the cases while it was more than $5 \mathrm{~cm}$ among 21 females (13.1\%) of them. Margins of the breast mass were irregular among $46.2 \%$ of the cases, and the mass was soft among 59 of the patients $(54.1 \%)$. Skin changes were recorded for $28(22.2 \%)$ of the cases, and 53 cases (34.9\%) had positive Axillary lymph nodes on physical examination.

Considering radiological and biopsy findings among the cases, Table 4 illustrates that the most recorded US finding was Fibrocystic disease $(64 ; 49.6 \%)$ followed with cancer related features $(29 ; 22.5 \%)$, breast abscess $(8.5 \%)$, and fibroadenoma 
Table 1. Personal and obstetric data for female patients with breast diseases in Najran, Southern Saudi Arabia.

\begin{tabular}{|c|c|c|c|}
\hline \multicolumn{2}{|c|}{ Personal \& obstetric data } & No & $\%$ \\
\hline \multirow{5}{*}{ Age in years } & $<20$ years & 17 & $8.1 \%$ \\
\hline & $20-30$ & 42 & $19.9 \%$ \\
\hline & $30-40$ & 65 & $30.8 \%$ \\
\hline & $40-50$ & 75 & $35.5 \%$ \\
\hline & $50+$ & 12 & $5.7 \%$ \\
\hline \multirow{3}{*}{ Marital status $(\mathrm{n}=82)$} & Single & 19 & $23.2 \%$ \\
\hline & Married & 59 & $72.0 \%$ \\
\hline & Divorced/widow & 4 & $4.9 \%$ \\
\hline Age of menarche & $<18$ years & 20 & $100.0 \%$ \\
\hline Regular menstrual cycle & Yes & 22 & $100.0 \%$ \\
\hline \multirow{2}{*}{ Age of menopause $(n=15)$} & Not at menopause & 10 & $66.7 \%$ \\
\hline & 40 - 49 years & 5 & $33.3 \%$ \\
\hline \multirow{3}{*}{ Age of pregnancy $(n=10)$} & $<20$ years & 1 & $10.0 \%$ \\
\hline & $20-30$ & 8 & $80.0 \%$ \\
\hline & $30+$ & 1 & $10.0 \%$ \\
\hline \multirow{3}{*}{ No. of pregnancies $(n=29)$} & Nulligravida & 3 & $10.3 \%$ \\
\hline & $1-3$ & 17 & $58.6 \%$ \\
\hline & $4+$ & 9 & $31.0 \%$ \\
\hline \multirow{7}{*}{ Co-morbidity } & None & 10 & $19.2 \%$ \\
\hline & $\mathrm{DM}$ & 5 & $9.6 \%$ \\
\hline & HTN & 7 & $13.5 \%$ \\
\hline & Hypothyroidism & 8 & $15.4 \%$ \\
\hline & Asthma & 3 & $5.8 \%$ \\
\hline & Others & 8 & $15.4 \%$ \\
\hline & Diabetic and HTN & 11 & $21.2 \%$ \\
\hline
\end{tabular}

Table 2. Factors related to have breast disease among female patients in Najran, Southern Saudi Arabia.

\begin{tabular}{|c|c|c|c|}
\hline \multicolumn{2}{|c|}{ Factors related to breast diseases } & No & $\%$ \\
\hline \multirow{2}{*}{ Oral contraceptive pills } & No & 12 & $60.0 \%$ \\
\hline & Yes & 8 & $40.0 \%$ \\
\hline \multirow{2}{*}{ Hormonal therapy } & No & 9 & $69.2 \%$ \\
\hline & Yes & 4 & $30.8 \%$ \\
\hline \multirow{2}{*}{ Family history of breast disease } & No & 43 & $76.8 \%$ \\
\hline & Yes & 13 & $23.2 \%$ \\
\hline \multirow{2}{*}{ Family history of other cancers } & No & 13 & $76.5 \%$ \\
\hline & Yes & 4 & $23.5 \%$ \\
\hline \multirow{2}{*}{ Know about breast screening } & No & 10 & $55.6 \%$ \\
\hline & Yes & 8 & $44.4 \%$ \\
\hline \multirow{2}{*}{ Regular Breast Examination } & No & 4 & $14.8 \%$ \\
\hline & Yes & 23 & $85.2 \%$ \\
\hline \multirow{2}{*}{ Who did the examination } & By herself & 12 & $52.2 \%$ \\
\hline & By physician & 11 & $47.8 \%$ \\
\hline \multirow{2}{*}{ Regular breast screening after age 40} & No & 3 & $75.0 \%$ \\
\hline & Yes & 1 & $25.0 \%$ \\
\hline
\end{tabular}


A. M. Alamri et al.

Table 3. Clinical data of breast diseases among female patients in Najran, Southern Saudi Arabia.

\begin{tabular}{|c|c|c|c|}
\hline Clinical data & & No & $\%$ \\
\hline \multirow{8}{*}{ Clinical signs \& symptoms } & Mass & 196 & $95.1 \%$ \\
\hline & Pain & 66 & $32.0 \%$ \\
\hline & Skin changes & 11 & $5.3 \%$ \\
\hline & Nipple changes & 8 & $3.9 \%$ \\
\hline & Swelling & 4 & $1.9 \%$ \\
\hline & Discharge & 2 & $1.0 \%$ \\
\hline & Others & 2 & $1.0 \%$ \\
\hline & Axillary mass & 1 & $0.5 \%$ \\
\hline \multirow{4}{*}{ Duration of symptoms } & $<1$ month & 31 & $23.5 \%$ \\
\hline & $1-2 \mathrm{~ms}$ & 29 & $22.0 \%$ \\
\hline & $3-6 \mathrm{~ms}$ & 20 & $15.2 \%$ \\
\hline & $>6$ months & 52 & $39.4 \%$ \\
\hline \multirow{3}{*}{ Side of lesion } & Right & 84 & $41.2 \%$ \\
\hline & Left & 101 & $49.5 \%$ \\
\hline & Bilateral & 19 & $9.3 \%$ \\
\hline \multirow{3}{*}{ Mass size } & $<2 \mathrm{~cm}$ & 60 & $37.5 \%$ \\
\hline & $2-5 \mathrm{~cm}$ & 79 & $49.4 \%$ \\
\hline & $>5 \mathrm{~cm}$ & 21 & $13.1 \%$ \\
\hline \multirow{2}{*}{ Margins of mass } & Irregular & 49 & $46.2 \%$ \\
\hline & Regular & 57 & $53.8 \%$ \\
\hline \multirow{2}{*}{ Mass consistency } & Soft & 59 & $54.1 \%$ \\
\hline & Hard & 50 & $45.9 \%$ \\
\hline \multirow[b]{2}{*}{ Skin changes } & No & 98 & $77.8 \%$ \\
\hline & Yes & 28 & $22.2 \%$ \\
\hline \multirow{2}{*}{ Nipple discharge } & No & 114 & $90.5 \%$ \\
\hline & Yes & 12 & $9.5 \%$ \\
\hline \multirow[b]{2}{*}{ Nipple retraction } & No & 89 & $84.8 \%$ \\
\hline & Yes & 16 & $15.2 \%$ \\
\hline \multirow{3}{*}{ Nipple destruction } & No & 90 & $98.9 \%$ \\
\hline & & & \\
\hline & Yes & 1 & $1.1 \%$ \\
\hline \multirow{3}{*}{ Positive axillary lymph nodes } & No & 99 & $65.1 \%$ \\
\hline & & & \\
\hline & Yes & 53 & $34.9 \%$ \\
\hline
\end{tabular}


Table 4. Radiological and biopsy findingsamongfemale patients with breast disease in Najran, Southern Saudi Arabia.

\begin{tabular}{|c|c|c|c|}
\hline $\begin{array}{l}\text { Radiological and biopsy } \\
\text { findings }\end{array}$ & & No & $\%$ \\
\hline \multirow{11}{*}{ US findings } & Fibrocystic disease & 64 & $49.6 \%$ \\
\hline & Cancer & 29 & $22.5 \%$ \\
\hline & Breast abscess & 11 & $8.5 \%$ \\
\hline & Fibroadenoma & 10 & $7.8 \%$ \\
\hline & Phyllodes & 5 & $3.9 \%$ \\
\hline & Unremarkable & 2 & $1.6 \%$ \\
\hline & Galactocele & 1 & $0.8 \%$ \\
\hline & Lactating adenoma & 1 & $0.8 \%$ \\
\hline & Mastitis & 1 & $0.8 \%$ \\
\hline & Mature adipose tissue with fibrous tissue & 1 & $0.8 \%$ \\
\hline & Antibioma & 1 & $0.8 \%$ \\
\hline \multirow{8}{*}{ Mammogram findings } & Speculated mass & 14 & $35.9 \%$ \\
\hline & Microcalcification & 10 & $25.6 \%$ \\
\hline & Microcalcification, Speculated mass & 9 & $23.0 \%$ \\
\hline & Texture distortion & 2 & $5.1 \%$ \\
\hline & Fatty glandular breast parenchyma & 1 & $2.6 \%$ \\
\hline & Mixed fibro-fatty glandular breast prynchema & 1 & $2.6 \%$ \\
\hline & Multi cystic & 1 & $2.6 \%$ \\
\hline & Oil cyst & 1 & $2.6 \%$ \\
\hline \multirow{2}{*}{ MRI impression } & Benign & 21 & $41.2 \%$ \\
\hline & Malignant & 30 & $58.8 \%$ \\
\hline \multirow{5}{*}{ Type of biopsy } & Excisional & 35 & $19.6 \%$ \\
\hline & True cut & 117 & $65.4 \%$ \\
\hline & Fine needle aspiration cytology (FANC) & 23 & $12.8 \%$ \\
\hline & Incisional & 3 & $1.7 \%$ \\
\hline & Lumpectomy & 1 & $.6 \%$ \\
\hline \multirow{2}{*}{ Final pathology report } & Benign & 124 & $63.9 \%$ \\
\hline & Malignant & 70 & $36.1 \%$ \\
\hline \multirow{7}{*}{ Nature of lesion } & Fibroadenoma & 66 & $42.9 \%$ \\
\hline & Fibrocystic & 29 & $18.8 \%$ \\
\hline & Invasive ductal carcinoma (IDC) & 29 & $18.8 \%$ \\
\hline & Breast abscess & 9 & $5.4 \%$ \\
\hline & Atypical ductal hyperplasia & 2 & $1.3 \%$ \\
\hline & Mucinous carcinoma & 2 & $1.3 \%$ \\
\hline & Antibioma & 1 & $0.6 \%$ \\
\hline
\end{tabular}




\begin{tabular}{|c|c|c|c|}
\hline & Acute and chronic breast inflammation & 1 & $0.6 \%$ \\
\hline & Ductal ectasia & 1 & $0.6 \%$ \\
\hline & Ductal hyperplasia & 1 & $0.6 \%$ \\
\hline & Epidermoid cyst & 1 & $0.6 \%$ \\
\hline & Fibroepithelial lesion & 1 & $0.6 \%$ \\
\hline & Gynecomastia & 1 & $0.6 \%$ \\
\hline & Invasive mammillary carcinoma & 1 & $0.6 \%$ \\
\hline & Invasive papillary $\mathrm{Ca}$ & 1 & $0.6 \%$ \\
\hline & Lactating adenoma & 1 & $0.6 \%$ \\
\hline & Myofibroblastic tumor & 1 & $0.6 \%$ \\
\hline & $\begin{array}{l}\text { Periductal \& perilobular chronic inflammatory } \\
\text { process }\end{array}$ & 1 & $0.6 \%$ \\
\hline & Phylloid with free margin less than $1 \mathrm{~mm}$ & 1 & $0.6 \%$ \\
\hline & Right axillary lipoma & 1 & $0.6 \%$ \\
\hline & Sebaceous cyst & 1 & $0.6 \%$ \\
\hline & Spidle cell tumor & 1 & $0.6 \%$ \\
\hline & Suggestive of tubular adenoma & 1 & $0.6 \%$ \\
\hline \multirow{2}{*}{ Ductal carcinoma in situ } & No & 18 & $56.3 \%$ \\
\hline & Yes & 14 & $43.8 \%$ \\
\hline
\end{tabular}

(10; 7.8\%). Mammogram findings were also recorded with the most recorded one was speculated mass $(14 ; 35.9 \%)$ followed with micro calcification (10; $25.6 \%)$, micro calcification with speculated mass $(9 ; 23 \%)$, and texture distortion (2; 5.1\%). MRI showed benign features among 21 cases (41.2\%) of the cases. As for biopsy, 117 females (65.4\%) of the cases undergone true cut biopsy followed with excisional biopsy (19.6\%), and fine needle aspiration biopsy (12.8\%). Benign findings based on final pathology report were diagnosed for $124(63.9 \%)$ of the cases with the most common finding was fibroadenoma (66; 42.9\%) followed with the fibrocystic disease $(29 ; 18.8 \%)$, IDC $(29 ; 18.8 \%)$ and breast abscess (9; $5.4 \%)$. Ductal carcinoma in situ was recorded for $43.8 \%$ of the cases.

Table 5 shows that Estrogens/Progestin Receptors were positive among 28 females (73.7\%) of the cases and Human epidermal growth factor receptor 2 (HER2) was positive for 11 cases (30.6\%) of the cases while Antigen Ki-67 was more than $12 \%$ among 10 cases (76.9\%).

Regarding surgery and clinical outcome (Table 6), excisional Biopsy was the most surgical procedure $(53 ; 41.1 \%)$ followed with modified radical mastectomy (28; $21.7 \%)$, lumpectomy $(23 ; 11.6 \%)$ while $17.8 \%$ of the cases were not operated.

\section{Discussion}

Researchers reported wide variability in the frequency and distribution of breast 
Table 5. Laboratory findings among female patients with breast disease in Najran, Southern Saudi Arabia.

\begin{tabular}{cccc}
\hline Laboratory findings & & No & $\%$ \\
\hline \multirow{2}{*}{ Estrogens/progestin receptors } & Negative & 10 & $26.3 \%$ \\
& Positive & 28 & $73.7 \%$ \\
\hline $\begin{array}{c}\text { Human epidermal growth factor } \\
\text { receptor 2 (HER2) }\end{array}$ & Negative & 25 & $69.4 \%$ \\
\hline Antigen Ki-67 & Positive & 11 & $30.6 \%$ \\
\hline & Less than 12\% & 3 & $23.1 \%$ \\
& More than 12\% & 10 & $76.9 \%$ \\
\hline
\end{tabular}

Table 6. Surgery data forfemale patients with breast disease in Najran, Southern Saudi Arabia.

\begin{tabular}{|c|c|c|}
\hline Surgery data & No & $\%$ \\
\hline \multicolumn{3}{|l|}{ Type of surgery } \\
\hline Excisional biopsy & 53 & $41.1 \%$ \\
\hline Modified radical mastectomy & 28 & $21.7 \%$ \\
\hline Not operated & 23 & $17.8 \%$ \\
\hline Lumpectomy & 15 & $11.6 \%$ \\
\hline Incision and drainage & 4 & $3.1 \%$ \\
\hline Drainage & 2 & $1.6 \%$ \\
\hline LAMA & 1 & $0.8 \%$ \\
\hline Not mentioned & 1 & $0.8 \%$ \\
\hline Simple mastectomy & 1 & $0.8 \%$ \\
\hline Drainage & 1 & $0.8 \%$ \\
\hline \multicolumn{3}{|l|}{ Surgery complications } \\
\hline None & 87 & $83.7 \%$ \\
\hline Seroma & 9 & $8.7 \%$ \\
\hline Wound infection & 5 & $4.8 \%$ \\
\hline Lymphedema & 2 & $1.9 \%$ \\
\hline Echymosis around the wound & 1 & $1.0 \%$ \\
\hline
\end{tabular}

ailments across the world [14] [15] [16]. Breast diseases more recorded among women than men, the prevalence rate in males ranging from $0 \%$ to $5.8 \%$ in most series, and the majority of male breast lesions are benign with gynaecomastia [17]. As for females, the pattern of pathology had high variability based on age and geographical location. Benign lesions are prevalent at all ages, constituting $48.9 \%$ to $57 \%$ with the main age of occurrence below the 30 years [18] [19].

Benign breast lesions are more presented than cancer [20] [21] [22]. Benign breast diseases, however, formed a heterogeneous group of disorders, including developmental abnormalities, epithelial and stromal proliferation, inflammatory lesions, and neoplasms [23]. Breast cancer incidence increased from 12.7 million 
in 2008 to 14.1 million in 2012, and this trend is predicted to increase in the future [24] [25]. It was estimated that worldwide over 508,000 women died in 2011 due to breast cancer [26]. Breast cancer survival rates vary greatly worldwide, ranging from $80 \%$ or over in North America, Sweden, and Japan to around $60 \%$ in middle-income countries and below $40 \%$ in low-income countries [27].

The current study aimed to assess the pattern of different breast diseases recorded for females in the south-western region, Saudi Arabia, during the period from January 2018 to January 2020. Also, the study aimed to assess the type of diagnostic and management methods with the clinical outcome. The study revealed that the majority of cases aged below 30 years and were married and still menstruating. Many risk factors for having breast diseases were recorded, including receiving oral contraceptive pills, hormonal therapy, positive family history, and irregular breast examination, especially at the age above 40 years. Breast mass was the most frequent complaint with breast pain with its size ranging from $2-5 \mathrm{~cm}$ in most cases and irregular margins in nearly half of the cases associated with Axillary lymph nodes in about 1 out of each 3 cases. Final pathology after a biopsy revealed that lesions were benign among two-thirds of the cases especially fibroadenoma, which is the most benign breast lesion. Regarding surgical intervention, modified radical mastectomy was needed for 1 out of each 5 cases, while only $11 \%$ of the cases undergone lumpectomy as the lesions were benign. Most of the cases had no post-operative complications less than $10 \%$ had seroma.

Generally, these findings were consistent with most of the literature. A study was conducted to assess benign breast lesions (BBD) in an African population [28] and recorded an increasing incidence of these benign lesions. The overall mean age for $\mathrm{BBD}$ was 27.5 years, $\mathrm{SD} \pm 11.3$, with an age range of 9 - 84 years and a peak age occurrence in the third decade. The single most common lesion was fibroadenoma accounting for $43.1 \%$ of cases, followed by fibrocystic change (23.8\%). A second study was conducted by Ayoade BA et al. 2012 [29] to Clinical Features and Pattern of Presentation of Breast Diseases in Surgical Outpatient Clinic of a Suburban Tertiary Hospital in South-West, Nigeria. The researchers reported that the commonest symptoms were breast lump in $91.7 \%$ patients, and breast pain in $23.1 \%$ patients. Forty four patients $(36.3 \%)$ had a malignant disease, seventy patients (57.8\%) had benign breast diseases, and seven were normal. Fifty nine of the 70 benign diseases were fibroadenoma. In India, Hatim K et al. 2017 [30] conducted a research to assess Patterns and prevalence of benign breast disease in Western India. The reported that the commonest benign breast lesion was fibroadenoma $(77.62 \%)$, followed by fibrocystic disease $(4.3 \%)$ and gynaecomastia $(4.3 \%)$.

Locally, Samir S et al. 1995 conducted a study to the spectrum of breast diseases in Saudi females [31]. The researchers reported that fibroadenoma was the most common lesion encountered $30.7 \%$, followed by fibrocystic condition $(21.1 \%)$, carcinoma $(14.9 \%)$, acute mastitis $(7.2 \%)$, duct ectasia $(4.9 \%)$, lactational ade- 
noma (4.8\%), intraductal papilloma (2.6\%), galactocele (2.4\%) and several less frequent lesions. A second study was conducted to assess histopathological patterns of breast lesions in Northern Saudi Arabia, 2017 [32]. The study revealed that $23.2 \%$ of the lesions were ductal carcinoma, $4.4 \%$ were lobular carcinoma, $1.9 \%$ were mixed tumours, while $64.6 \%$ were fibroadenoma.

When local breast disease distribution patterns are known, skills related to diagnosis and management can be made with a sound degree of certainty. In addition, resource allocation and planning can be better allied. This is true mainly in low income countries where a large population of individuals may not afford diagnostic and management costs.

\section{Conclusion and Recommendations}

In conclusion, benign breast diseases (BBD) were the most recorded among $\mathrm{Na}$ jran females, especially fibroadenoma, with low post surgical complications. The better reporting system should be initiated, and well training for the physicians is mandatory to improve the quality of available data, and research based on these data and achieve better and more realistic conclusions for planning and resource allocation.

\section{Ethical Considerations}

The study was conducted in accordance with the Declaration of Helsinki, and the protocol was approved by the Ethics and Research Committee of the College of Medicine of Najran University.

\section{Limitations of the Study}

Irrespective of the variety of collected clinical data in the current study, but there were two main limitations. The first is the sample size, which was due to reviewing only 2 years' cases, but this was due to a poor recording system, which somewhat primitive. The second was the high missing rate in the data for the cases, which also related to the primitive recording system and lack of physician's experience regarding these cases management guidelines.

\section{Authors' Contributions}

Conceptualization, Abdulrahman Manaa sultan Alamri; methodology, Abdulrahman Manaa sultan Alamri, Saeed Ali Alsareii; data curation, Hajr Hassan Al-Wadei, Awad Mohammed Al-Qahtani, Salem Ali Alatef Sultan, Sara Ali Alshamrani, Ahmed Hamzah Almakrami, Abdullah Ahmed Daiel; writing original draft preparation, Ahlam Yahya Alyami, Ashwaq Mousa Hommadi, Yagoub Mohammed Tahir Ali; funding acquisition, All participants. All authors have read and agreed to the published version of the manuscript.

\section{Funding}

This research was funded by all authors. No funding agency. 


\section{Acknowledgements}

All participants and included females were acknowledged.

\section{Conflicts of Interest}

The authors declare no conflict of interest.

\section{References}

[1] Cosgrove, D.O., Kedar, R.P., Bamber, J.C., Al-Murrani, B.A., Davey, J.B., Fisher, C., McKinna, J.A., Svensson, W.E., Tohno, E. and Vagios, E. (1993) Breast Diseases: Color Doppler US in Differential Diagnosis. Radiology, 189, 99-104. https://doi.org/10.1148/radiology.189.1.8372225

[2] Salzman, B., Fleegle, S. and Tully, A.S. (2012) Common Breast Problems. American Family Physician, 86, 343-349.

[3] Hatim, K.S., Laxmikant, N.S. and Mulla, T. (2017) Patterns and Prevalence of Benign Breast Disease in Western India. International Journal of Research in Medical Sciences, 5, 684-688. https://doi.org/10.18203/2320-6012.ijrms20170174

[4] Aslam, H. M., Saleem, S., Shaikh, H. A., Shahid, N., Mughal, A. and Umah, R. (2013) Clinico-Pathological Profile of Patients with Breast Diseases. Diagnostic Pathology, 8, 77. https://doi.org/10.1186/1746-1596-8-77

[5] American Cancer Society. Atlanta: American Cancer Society. Breast Cancer Facts and Figures.

https://www.cancer.org/research/cancer-facts-statistics/breast-cancer-facts-figures.h $\underline{\mathrm{tml}}$

[6] Okoth, C., Galukande, M., Jombwe, J. and Wamala, D. (2013) Benign Proliferative Breast Diseases among Femalepatients at a Sub Saharan Africa Tertiary Hospital: A Cross Sectional Study. BMC Surgery, 13, 1-9. https://doi.org/10.1186/1471-2482-13-9

[7] Chalya, P.L., Manyama, M., Rambau, P.F., Kapesa, A., Ngallaba, S.E., Masalu, N. and Mabula, J.B. (2016) Clinicopathological Pattern of Benign Breast Diseases among Female Patients at a Tertiary Health Institution in Tanzania. Tanzania Journal of Health Research, 18, 1.

[8] Clavel-Chapelon, F. and Gerber, M. (2002) Reproductive Factors and Breast Cancer Risk. Do They Differ According to Age at Diagnosis? Breast Cancer Research and Treatment, 72, 107-115. https://doi.org/10.1023/A:1014891216621

[9] Coriaty Nelson, Z., Ray, R.M., Gao, D.L. and Thomas, D.B. (2002) Risk Factors for Fibroadenoma in a Cohort of Female Textile Workers in Shanghai, China. American Journal of Epidemiology, 156, 599-605. https://doi.org/10.1093/aje/kwf094

[10] Gukas, I.D., Jennings, B.A., Mandong, B.M., Igun, G.O., Girling, A.C., Manasseh, A.N., et al. (2005) Clinicopathological Features and Molecular Markers of Breast Cancer in Jos. West African Journal of Medicine, 24, 209-213. https://doi.org/10.4314/wajm.v24i3.28220

[11] Anyanwu, S.N. (2000) Fibro-Adenoma of the Breast in Nigerian Igbos. South African Medical Journal, 90, 1223-1226.

[12] Ntekim, A., Nufu, F.T. and Campbell, O.B. (2009) Breast Cancer in Young Women in Ibadan, Nigeria. Afr Health Sci., 9, 242-246.

[13] Saunders, C.M. and Baum, C. (2000) The Breast in Bailey and Love's Short Practice of Surgery. In: Russell, R.C., Williams, N.S. and Bulstrode, C.J., Eds., Bailey and 
Love's Short Practice of Surgery, 23rd Edition, Arnold, London, 750-752.

[14] Chiedozi, L.C., El-Hag, I.A. and Kollur, S.M. (2003) Breast Diseases in the Northern Region of Saudi Arabia. Saudi Medical Journal, 6, 623-627.

[15] Jamal, A.A. (2001) Pattern of Breast Diseases in a Teaching Hospital in Jeddah, Saudi Arabia. Saudi Medical Journal, 2, 110-113.

[16] Adesunkanmi, A.R. and Agbakwuru, E.A. (2001) Benign Breast Diseases at Wesley Guild Hospital, Ilesha Nigeria. West African Journal of Medicine, 2, 146-151.

[17] Chaudhuri, M., Sens, S. and Sengupta, J. (1995) Breast Lumps: A Study of 10 Years. Journal of the Indian Medical Association, 12, 455-457.

[18] Adeniji, K.A., Adelusola, K.A. and Odesanmi, W.O. (1997) Benign Disease of the Breast in Ile-Ife: A 10 Year Experience and Literature Review. Central African Journal of Medicine, 5, 140-143.

[19] Mansoor, I. (2001) Profile of female breast lesions in Saudi Arabia. Journal of Pakistan Medical Association, 7, 243-247.

[20] Yusufu, L.M., Odigie, V.I. and Mohammed, A. (2003) Breast Masses in Zaria, Nigeria. Annals of African Medicine, 2, 13-16.

[21] Ochicha, O., Edino, S.T., Mohammed, A.Z. and Amin, S.N. (2002) Benign Breast Lesions in Kano. Nigerian Journal of Surgical Research, 4, 1-5. https://doi.org/10.4314/njsr.v4i1.12162

[22] Anyikam, A., Nzegwu, M.A., Ozumba, B.C., Okoye, I. and Olusina, D.B. (2008) Benign Breast Lesions in Eastern Nigeria. Saudi Medical Journal, 29, 241-244.

[23] Tavassoli, F.A. and Devilee, P. (2003) World Health Organization Histological Classification of Tumours of the Breast in Pathology and Genetics of Tumours of the Breast and Female Genital Organs. IARC, France.

[24] International Agency for Research on Cancer (2008) Cancer Incidence and Mortality World Wide. International Agency for Research on Cancer. IARC Cancer, Lyon. https://www.iarc.fr/wp-content/uploads/2018/07/pr223_E.pdf

[25] Ferlay, J., Shin, H.R., Bray, F., Forman, D., Mathers, C. and Parkin, D. (2013) Cancer Incidence and Mortality Worldwide. International Agency for Research on Cancer, Lyon, France, 120-163.

[26] World Health Organization (2013) Global Health Estimates. World Health Organization, Geneva?

[27] Sun, J., Chen, X., Wang, Z., Guo, M., Shi, H., Wang, X., Cheng, L. and Zhou, M. (2015) A Potential Prognostic Long Non-Coding RNA Signature to Predict Metastasis-Free Survival of Breast Cancer Patients. Scientific Reports, 9 November 2015, 5, 16553. https://doi.org/10.1038/srep16553

[28] Olu-Eddo, A.N. and Ugiagbe, E.E. (2011) Benign Breast Lesions in an African Population: A 25-Year Histopathological Review of 1864 Cases. Nigerian Medical Journal: Journal of the Nigeria Medical Association, 52, 211. https://doi.org/10.4103/0300-1652.93790

[29] Ayoade, B.A., Tade, A.O. and Salami, B.A. (2012) Clinical Features and Pattern of Presentation of Breast Diseases in Surgical Outpatient Clinic of a Suburban Tertiary Hospital in South-West Nigeria. Nigerian Journal of Surgery, 18, 1.

[30] Hatim, K.S., Laxmikant, N.S. and Mulla, T. (2017) Patterns and Prevalence of Benign Breast Disease in Western India. International Journal of Research in Medical Sciences, 5, 684-688. https://doi.org/10.18203/2320-6012.ijrms20170174

[31] Amr, S.S., Sa'di, A.R., Ilahi, F. and Sheikh, S.S. (1995) The Spectrum of Breast Dis- 
eases in Saudi Arab Females: A 26 Year Pathological Survey at Dhahran Health Center. Annals of Saudi Medicine, 15, 125-132.

https://doi.org/10.5144/0256-4947.1995.125

[32] Ahmed, H.G., Al-Shammeri, K.J., Alrashidi, A.G., Alrashedi, S.A., Alenazi, F.S., Seada, L.S. and Ashankyty, I.M. (2017) Histopathologic Patterns of Breast Lesions in Northern Saudi Arabia. International Journal of Medical Research \& Health Sciences, 6, 54-64. 